\title{
The Tragedy of Unpersuasive Power: The Convention on Biological Diversity as Exemplary
}

\author{
Joseph Henry Vogel ${ }^{1}$ \\ ${ }^{1}$ Department of Economics, University of Puerto Rico-Rio Piedras, USA \\ Correspondence: Joseph Henry Vogel, Department of Economics, University of Puerto Rico, PO Box 23345, San \\ Juan, Puerto Rico, USA. Tel: 1-787-764-0000, ext. 2451. E-mail: josephvogel@usa.net
}

Received: August 31, 2013 Accepted: September 12, 2013 Online Published: September 23, 2013

doi:10.5539/ijb.v5n4p44

URL: http://dx.doi.org/10.5539/ijb.v5n4p44

\begin{abstract}
The complement to "The Tragedy of the Commons" is "The Tragedy of Unpersuasive Power." A class of problems exists for which technical solutions go unheeded. Logic and evidence do not prevail. Nevertheless, the fallacies and rhetoric do make sense in the light of human evolution as eusocial: groupthink is the consequence of group selection. Exemplary of the class of problems is "access to genetic resources [and] the fair and equitable sharing of benefits arising from the utilization of genetic resources," (ABS) of the 1993 United Nations Convention on Biological Diversity (CBD). Capacious language in the 2010 Nagoya Protocol on ABS has immortalized contentious issues which could have been resolved through the economics of information, elaborated since 1992. The online discussion groups of the ABS Clearing House afford a natural experiment to test the tragedy. The solution is "delegated delegation" driven by a quest for legacy by the leadership.
\end{abstract}

Keywords: delegation, fallacies, evolutionary psychology, eusociality, governance, group selection

\section{Introduction}

In a disquieting editorial on nuclear proliferation, Lawrence Krauss warns that "until science and data become central to informing our public policies, our civilization will be hamstrung in confronting the gravest threats to its survival." The author, a public intellectual and theoretical physicist, recognizes that his argument is generic. "[D]istinguished scientific minds at our research universities and other national labs - provide advice that is routinely ignored" (2013). The observation is reminiscent of the quote from two nuclear scientists that opens "The Tragedy of the Commons" by Garrett Hardin:

"Both sides in the arms race are confronted by the dilemma of steadily increasing military power and steadily decreasing national security. It is our considered professional judgment that this dilemma has no technical solution. If the great powers continue to look for solutions in the area of science and technology only, the result will be to worsen the situation" [italics in original] (1968).

A comparison of the warnings, separated by a half century, reveals a sea change in governance. Nuclear scientists, once consulted in the hope of a technical solution, are now dismissed. Perhaps the most disturbing aspect of Krauss' observation is that the nuclear scientists are not alone. A class of problems exists where technical solutions are known and go unimplemented. Logic and evidence do not prevail. In the spirit of Hardin, one may say that if the experts continue to voice only the technical solutions, the situation will worsen. The reason for dismissal is not for lack of exposure. It lies elsewhere and portends tragedy.

Outstanding in the class of problems left unresolved by a known technical solution is "access to genetic resources [and] the fair and equitable sharing of benefits arising from the utilization of genetic resources" (United Nations Convention on Biological Diversity, 1992). The phrase in quotes goes by the acronym ABS, where the first letter stands for access and the last two, for benefit sharing. Protests over unfairness and inequity in ABS have bedeviled the United Nations Convention on Biological Diversity (CBD) since its signature in 1992 at the historic Earth Summit in Rio de Janeiro. The subsequent eleven Conferences of the Parties (COPs) to the CBD have not only failed to achieve a workable framework for ABS but actively undermined the technical solution to incentivize conservation. Using mass extinction as exemplary of the "gravest threats" to human survival, an interdisciplinary analysis of ABS can shed light on what should be the broader role of science in policymaking. 


\section{An unimplemented Technical Solution vs. Brokered Compromises}

Identification of egregious errors in the evolving policies of the $\mathrm{CBD}$ is a useful starting point. The most egregious seems to be The Bonn Guidelines on ABS adopted at COP6 in 2002. The Guidelines list twenty-seven categories of benefits, broken down into seventeen non-monetary benefits and ten, monetary. The length of the list serves as a camouflage for the one category that could serve as a measuring rod for value: royalties on inventions that utilize genetic resources. But the smokescreen is not the worst aspect of the Guidelines. That distinction belongs to the royalty to be negotiated. The Guidelines are saying: Let the reverse bidding begin! In a market with many suppliers, the microeconomics is unequivocal: the percentage royalty rate will drop to whatever reflects the marginal cost of sampling genetic resources, i.e., essentially nothing (Vogel, 2007).

The COPs occur in ecological time which is measured in years and decades, roughly the same velocity at which the mega-diverse countries are losing habitats to "development." Having once called the resulting mass extinction "the folly our descendants are least likely to forgive," second only to nuclear war, the naturalist E.O. Wilson has become, twenty-eight years later, exasperated. "We are needlessly turning the gold we inherited from our forebears into straw, and for that we will be despised..." (2012). He complains of "battle fatigue" (2002).

The technical solution for ABS derives from "the economics of information" in "the science which studies human behavior as a relationship between given ends and scarce means which have alternative uses" (Robbins, 1932). Pioneers in the economics of information have won the Nobel Memorial Prize in 1974, 1982, and 2001 (Nobelprize.org, 2013). Nevertheless, the Ratified Parties have ignored the application of the economics of information despite its recurrent appearance in the literature since 1992 (Oduardo-Sierra, et al., 2012). Although economics can be abstruse, its studied ignorance in the COPs is not due to any inherent complexity. The solution is fairly simple and a one-page description would even do it justice.

The page would begin with the Chinese proverb that Wilson loves to cite: "the first step toward wisdom is getting the names of things right" (Wilson, 1998). Ever since Francis Crick's 1970 publication of "The Central Dogma of Molecular Biology," the immaterial nature of "genetic resources" has been manifest in the literature. "Genetic information" is ubiquitous. For the purposes of ABS, the economist can do Crick one better and suggest "natural information," thereby sweeping biomimicry and non-human culture into the scope of the CBD (Vogel, 2012). Biologists should not object; Wilson also writes that reductionism is "the virtually unchallenged linchpin of the natural sciences" (Wilson, 1994).

The rest of the one-page description has appeared many times and in many venues. The following is an example.

"For material goods, competition promotes efficiency and equity; for information goods, competition promotes neither (Samuelson \& Nordhaus, 2005). The exception of information goods from the standard economics analysis inheres to the high fixed costs of research and development and the low marginal costs of reproduction. Without protection from competitors, creators cannot recoup the fixed costs of their creations. Why spend vast sums to create something if everyone can cheaply copy it? Time-limited monopoly rights are the solution.

Inasmuch as genes are information - a sequence of nucleotide bases that can be copied - the analogy with intellectual property is really a homology. Conservationists cannot recoup the opportunity costs of conservation if anyone can trade freely in the same natural information, usually geographically dispersed. Why conserve a vast habitat if you can take out a few samples? Oligopoly rights over natural information are the analog to the monopoly rights over artificial information. Such framing of ABS also extends to enforcement. Similar to artificial information, the illicit flow of natural information cannot be impeded physically. The fence around information must be metaphorical, i.e., a legal instrument. So the economics-of-information narrative ends with analogous institutions: intellectual property has TRIPs [Trade Related Intellectual Property Rights] and WIPO [World Intellectual Property Organization]; genetic resources should have an International Regime on ABS under the Secretariat to the UN CBD” (Marrero-Girona \& Vogel, 2012).

Instead of elaborating the institutional mechanisms of such "bounded openness" (Vogel et al., 2013), the Ratified Parties have agreed to disagree in COP after COP. Capacious language has been the enabler of fairly meaningless consensus. With much fanfare and at the eleventh hour of COP10, emerged "The Nagoya Protocol on Access to Genetic Resources and the Fair and Equitable Sharing of Benefits Arising from their Utilization to the Convention on Biological Diversity" (NP).

Scholarly analysis began as soon as the final text of the NP was uploaded into cyberspace. Evanson Kamau et al., skillfully identified thirteen contentious issues of ABS and explained how every one was left unresolved (2010). Using the list of Kamau et al., Joseph Henry Vogel et al. showed that the economics of information would have resolved eleven of the thirteen issues identified (2011). For the two still unresolved, Simon West explained how 
the NP institutionalizes exclusion of traditional communities (2012). But not all scholars were so negative. Many held out hope for future COPs. Matthias Buck and Clare Hamilton regard the NP a "major achievement" in "global environmental governance" (2011). Two years later at CO11, negotiations bogged down in the conundrum of "resource mobilization" for implementation (United Nations Convention on Biological Diversity, 2012) - a euphemism for the misalignment of incentives which the technical solution addresses headlong.

The NP contains 36 articles and only one picks up elements of the known technical solution. Article 10 is entitled "Global Multilateral Benefit-Sharing Mechanism" and addresses "transboundary situations." From the reductionist viewpoint of natural information, the delineation of boundaries begins with taxonomy and extends to geography. Because principal agents in patented biotechnologies are often found in various species dispersed over national borders, transboundary situations may be the rule and not the exception. Like the counterproductive Bonn Guidelines, Article 10 does not fix a royalty percentage as part of the "modality." In fact, it does almost nothing. As elaborated in the IUCN Explanatory Guide, Article 10 "does not create a global multilateral benefit-sharing mechanism, but rather instructs Parties to deliberate on whether such a mechanism would be required and if so, how it would operate" (Greiber, 2012). The first three words of Article 10 set the stage for much more talk in many future COPs: "Parties shall consider..."

\section{Fallacies and Groupthink}

A single fallacy can derail an argument. Before further examining ABS as exemplary of tragedy of unpersuasive power, a close look at some common fallacies is fruitful. There are many from which to choose. The Nizkor Project on the World Wide Web lists 42 and new fallacies are being identified (2013). Billionaire currency speculator George Soros has elaborated two that beset formal economics (2010). They are the Enlightenment Fallacy and the Post-Modern Fallacy. The former arises in the belief that reason will prevail given sufficient time. The economist will recall John Maynard Keynes' remark from The General Theory "I am sure that the power of vested interests is vastly exaggerated compared with the gradual encroachment of ideas" (1936). Such confidence in the persuasive power of ideas is the Enlightenment Fallacy.

The Post-Modern Fallacy is the opposite. Because truth does not reign supreme, many politicians feel no compunction to acknowledge reality. What matters are perceptions in the struggle for power and its maintenance. The strategy is fallacious because reality does matter and can be unforgiving. The novel Nineteen Eighty-Four captures the phenomenon so well that the author's name has become eponymous. An Orwellianism apropos for ABS can be gleaned in Barack Obama's speech at the 2009 London Summit. The 44th President of the United States waxed eloquently about "sustained growth" even though the oxymoron presages ecological collapse (CBCNEWS, 2009). Should future voters assign blame to whomever is then in office, the Post-Hoc Fallacy comes to the fore. But people can learn. Why don't they wise up?

The economist Mancur Olson would respond that they do wise up. Out of selfish interests, they do nothing. For any individual, the benefits of activism do not justify the costs even though the benefits for society swamp the costs (1965). Asymmetrically, the defenders of a dysfunctional policy do not suffer the same free-rider problem. They are bolstered by a professional culture that promotes the interests of the group. Such generalizations apply easily to ABS. Long time participants to the COPs have noted that the ABS discussion is "very legalistic" (Vernooy \& Ruiz, 2012). As Nobel Memorial Laureate Joseph E. Stiglitz discerns, "[f]or lawyers, transaction costs are a benefit, because they are a source of their income" (2008). An anecdote may be illustrative. In a letter-to-the-editor of Nature Biotechnology, entitled "Wanted: Bioprospecting Consultants," the unemployed lawyer will delight:

"[T]he Nagoya Protocol presents several hurdles to any company or individual seeking to legitimately collect and invest in the development of products based on natural resources. Together with the proliferation of overlapping treaties and agreements and the involvement of an increasingly complex patchwork of international agencies, bioprospecting now represents a daunting legal challenge for any entity seeking to access the genetic resources of a particular country. For these reasons, we believe there is an urgent need for consultants to facilitate partnerships and foster trust among players in the bioprospecting process" (Watanabe \& Teh, 2011).

The multiple sources of lawyer income arising from ABS have been systematized, unintentionally. Swen C. Renner et al. provide a comprehensive survey in "Import and export of biological samples from tropical countries-considerations and guidelines for research teams." The checklist of most likely needed permits is in the format of a landscaped table that extends two pages in 8.5-point typeface (2012). Nevertheless, the authors conclude that "[t]he new ABS regulations do not necessarily confront scientists with unachievable obligations." Belying any such hope is the last of the five major problems identified in the conclusion: "Some regulations are 
inconsistent or contradictory. To allow compliance with all regulations, legislators should revise all potential contradictions to facilitate researchers' work and output."

ABS policymaking seems to epitomize "the principal-agent problem" (Stiglitz, 1987). Vast and uncoordinated principals (the citizenry) are pitted against the agents (the delegations) who ultimately derive power from vested interests (industrial users). However, to invoke the principal-agent problem risks what Nicolas Georgescu-Roegen identified as the sin of standard economics, "The Fallacy of Misplaced Concreteness" (Daly, 1991): entertaining only the questions permitted by the methodology, viz. expressions of selfishness. Economics has long assumed that selfishness is the only behavior worthy of study. As Wilson discerns "[e]conomists have by and large steered around [human nature]" (2012). Besides committing the Fallacy of Misplaced Concreteness, the over reliance on the assumption of selfishness hazards the Fallacy of Composition, which was foundational for the Keynesian revolution (Leijonhufvud, 1968). For ABS, one should not assume that what is true of the part (selfishness of the high-ranking delegate) is true of the whole (selfishness of his or her subordinates). To avoid committing both fallacies simultaneously, one must examine the dominance hierarchy of the agents.

Whenever the alpha male or female makes the wrong decision for the principals but the right decision for him or herself, selfishness is explanatory. Because subordinates do not voice disagreement, one suspects coercion. Al Gore quotes Upton Sinclair in An Inconvenient Truth "It is difficult to get a man to understand something when his salary depends upon his not understanding it" (2006). Hence, the assumption of selfish interests appears robust, especially in the corporate world. But for the international bureaucracy, such attribution contradicts the tenure of low-ranking bureaucrats. In the case of the $\mathrm{CBD}$, the vast majority of $\mathrm{COP}$ delegates appear to be dedicated public servants. An alternative explanation for the studious ignorance of the technical solution is an Appeal to Authority compounded by the Naturalistic Fallacy of Ethics, viz. what is (decisions emanating from the top), should be. Subservience within and among delegations is pronounced "team playing" and literally cheered as witnessed in the announcement of the NP at the close of COP10 on October 29, 2010 (ICTSD, 2010). For the industry lobbyist, all that matters is alignment of the top agent and delegations with the vested interest. The rest fall in line.

"Groupthink" coheres so well with Nineteen Eighty-Four that the literati even mistake its etymology as Orwellian.

A disclaimer is warranted. To do science one must commit the Fallacy of Misplaced Concreteness to some degree. Indeed, the discussion here does not entertain all 42 known fallacies that may be present in dysfunctional policymaking. But it does discuss many more than would a typical textbook in economics. In the classic ECONOMICS, Paul Samuelson and William Nordhaus list only three fallacies to orient the novice in a section entitled, not facetiously, "The Logic of Economics" (2005); the rival textbook by Gregory Mankiw indexes none. To avert the tragedy of unpersuasive power, some cherry picking must continue. The question becomes where? Human biology is fertile ground and a close look at "eusociality" would not be a detour. Indeed, the tragedy of unpersuasive power only makes sense in the light of evolution.

\section{Rehabilitation of Group Selection and Human Instinct}

Sociobiology is a watershed in the history of thought. Wilson published the tome in 1975 and all hell broke loose with the last chapter "Man: From Sociobiology to Sociology." Outrage was mobilized through an umbrella movement "Science for the People" and the Boston-based "Sociobiology Study Group." The strident pronouncements from the critics led Wilson to identify himself as a victim of "academic vigilantism" (1976). To the defenders of "the new synthesis," Wilson's oeuvre was scurrilously conflated with the discredited theories of biological determinism. A thorough literature survey would have forewarned Wilson of the backlash. The medical educator Leon Eisenberg launched a preemptive strike in 1972 with the pithy phrase "man is his own chief product," heaping special scorn on the policy implications of any reductionist approach. "[T]he behavior of men is not independent of the theories of human behavior that men adopt." In the first ten years of Wilson's "new synthesis," the drumbeat never let up. The most rigorous dissection of the entire field was also its most merciless critique: Vaulting Ambition: Sociobiology and the Quest for Human Nature (Kitcher, 1985). A pall had been cast. To proceed, the exponents would need a name change and "evolutionary psychology" seemed as good as any.

In renaming the discipline, human sociobiologists-cum-evolutionary psychologists evidenced post-modern thinking. Care was taken to distance research streams from the baggage of the old "nurture vs. nature" debates. "Instinct" exited unceremoniously from the conversation (Hrdy, 1981) and "gene-culture co-evolution" entered, full force (Lumsden \& Wilson, 1981a). The preferred metaphor would be a leash. Genes and culture tug on each other through time (Lumsden \& Wilson, 1981b). Explicit in the framework was the gene as the unit of selection, 
an abstraction already popularized in 1976 through The Selfish Gene. The author, Richard Dawkins, emphasized that Homo sapiens was no exception and criticized "Robert Ardrey [who] in The Social Contract, used the group-selection theory to account for the whole of social order in general."

On different grounds, Wilson had also dismissed Ardrey, along with the like-minded Desmond Morris, Robin Fox and Lionel Tiger. The biosocial anthropologists were not playing by the rules of science, Wilson contended. Plausible evolutionary explanations were not enough in "the reconstruction of human and social evolution" (1975); theories must generate falsifiable hypotheses. Ironically, the charge against Ardrey et al. was also leveled against Wilson, whose explanations were being dismissed as "just-so stories," which became the signature invocation of Stephen J. Gould (1978). Roughly a generation lapsed before evolutionary psychologists would rebut the Kipling epithet. David P. Barash and Judith Eve Lipton write "Scientists don't simply test a random array of hypotheses; rather, they evaluate outcomes only after certain possibilities." Seen thus, "just-so stories don't merely lead, on occasion, to reputable science; they may well be a prerequisite" (2010).

What was Adrey's untestable explanation or just-so story? The anthropologist and playwright had the temerity to speculate about human behavior based on broad patterns of animal behavior. "Is Homo sapiens a territorial species? Do we stake out property, chase off trespassers, defend our countries because we are sapient, or because we are animals?" (1966). In riveting prose, Adrey explained that we stake out property, etc., because we are animals. He attributed the ultimate causation of "the territorial imperative" to group selection and cited Alfred Russel Wallace's exposition before the London Anthropological Society in 1864 and Darwin's The Descent of Man, published in 1871.

Adhering to the rules of science, Wilson would eventually conclude that group selection was the less falsified hypothesis. Analogous to ants, bees, termites, and wasps, humans are eusocial, "meaning group members containing multiple generations and prone to perform altruistic acts as part of their division of labor" (2012). A careful reading of Sociobiology foreshadows the historic about-face: "The good researcher does not grieve over the death of a particular hypothesis. Since he has attempted to set up multiple hypotheses he is committed to the survival of no one of them, but is interested to see how simply they can be formulated and how decisively they can be made to compete" (1975). By reversing himself and allowing multi-level selection, some thirty years later, Wilson epitomizes the Enlightenment. Once the falsifiable hypothesis passes a threshold of evidence, acceptance follows. Without chagrin, Wilson states "After a close study, I changed my mind" (2012).

The tragedy of unpersuasive power occurs when minds do not change in the light of the logic exposed and the evidence accumulated. For the class of problems for which technical solutions are known, one may hypothesize that groupthink is the proximate causation for studied ignorance and group selection, the ultimate causation. Over tens of thousands of years, acceptance of a suggestion arising from outside the group would have threatened the dominance hierarchy from within. In The Social Conquest of Earth, Wilson writes "[t]he tendency to form groups and then favor in-group members has the earmarks of instinct" (2012). Later, he alerts the reader that "the more elaborate and expensive the nest is in energy and time, the greater the fierceness of the ants that defend it" [italics in original].

In the run-up to COP10, the Ratified Parties met in Cali, Colombia for the Ninth Working Group of the Convention on Biological Diversity on ABS. The application of the economics of information was exposed one last time in the side event forum "Key Issues on The Final Stage of IR [International Regime] Negotiations: Reflections and Proposals," sponsored by several renowned conservation organizations. In the accompanying paper, the presenters strongly recommended that "economic logic prevail" and recognized that "such a shift may be nothing easy. Observing the similarities in social behavior between humans and the apes, the primatologist Frans de Waal comments '...the persuasive power of logic is surprisingly limited"' (Ruiz, et al., 2010). The audience numbered barely more people than those who were presenting. More disturbing, no delegates from the 193 Ratified Parties attended.

Applying Wilson's insight, the "nest" of ABS policymaking is "elaborate and expensive...in energy and time." "Fierceness" in defense can manifest itself in studied ignorance. Change must emanate from above. The problem of governance is one of biology.

\section{Can Legacy Drive "Delegated Delegation" for ABS?}

On the eve of Barack Obama's 2013 State of the Union Address, The Economist ran the story "How will history see me?" The cover photograph was of the president fixing his tie in the mirror, chin upturned. The article dealt with foreign (read war) policy and other issues where Obama could "seize history" (2013). Climate change was a brief paragraph and mass extinction, unmentioned. In contrast to the specific possibilities floated in The 
Economist, the suggestion here is generic. The President can seize history by transcending tribal alliances and empowering expertise.

A few excerpts from Obama's address augur poorly for any such transcendence and empowerment. "The American people don't expect government to solve every problem. They don't expect those of us in this chamber to agree on every issue. But they do expect us to put the nation's interests before party. They do expect us to forge reasonable compromise where we can. For they know that America moves forward only when we do so together; and that the responsibility of improving this union remains the task of us all" (2013). The rhetoric assumes a competency that no one has, much less everyone. But it does sound good and coheres with Soros' observation that people "do not mind being deceived; indeed, they seem to positively invite it" (2010). Precisely because the known technical solutions require expertise, "the responsibility of improv[ement]" cannot remain "the task of us all."

The foolishness of "forging compromise" rather than implementing solutions was put in high relief in the very next breath. Obama begins the first of a dozen paragraphs on deficit reduction with a disarming premise: "Now most of us agree that a plan to reduce the deficit must be part of our agenda." The statement is true but must be qualified. Those "of us" who do not agree to a "plan to reduce the deficit" are the economists, with the exception of a few cranks. Indeed, the central message of economics, ever since Keynes, has been to increase deficit spending in times of unemployment. The point has been made tirelessly by Nobel Memorial Laureate Paul Krugman in his column for The New York Times (2013a). Given the stature of the columnist and of the venue, a natural experiment has occurred in the tragedy of unpersuasive power (2013b).

Despite grave threats that lend themselves to resolution through expertise, experts seem to follow the dictum attributed to Sir Robert Lowe "We must educate our masters" (Knight, 2013). In our age of nuclear proliferation, climate fluctuations and mass extinction, the Victorian sentiment is dangerously anachronistic. Should the masters fail to listen much less learn, everyone pays a terrible price. Less graciously, we must persuade our masters to "delegate delegation" (Ehrlich \& Ehrlich, 2004). The alliteration of verb and noun is Paul and Anne Ehrlich's witticism. In a society of delegated delegation, the task for the Head of State is leadership in explaining how technocracy is an efficient division of labor.

Such thinking is not new. Alan S. Blinder made the case forcefully in the Foreign Affairs article "Is Government Too Political?" (1997). The Ehrlichs extended Blinder's affirmative answer to a host of environmental issues and urged establishment of a "relatively insulated independent agency" to implement a "very tough federal land-use policy." Like Blinder, they also perceive a benefit to the politician. "Elected representatives should be delighted to be distanced from many of the tough decision necessitated by humanity's collision course with the natural world."

Social critics may not be hopeful. Noam Chomsky observes that "[p]ower systems, whatever they are, very rarely abdicate their power cheerfully" (2013). The expansion of studied ignorance over the last half century supports Chomsky's grim assessment. How do we motivate Heads of State to delegate delegation? The pursuit need not be quixotic.

Keynes famously said that we are all dead in the long run (Keynes, 1923). Unintentionally, the quip contradicts organized religions, where everlasting life is the reward for Homo religioso. The all-too-human quest for symbolic eternity may point the way toward institutionalizing delegated delegation. Until recently, the publication of life narratives was beyond the reach of almost everyone. In his autobiography, Wilson marvels over the erasure of familial contexts and cerebral memories "almost as though they never existed" (Wilson, 1994). With cheap storage in server factories and a good Internet connection, the salient experiences of everyone can be recorded and retrieved on demand. One suspects that few autobiographies will ever enjoy many hits.

The same information technology that permits massive storage undercuts the hagiographies which are typical of nation building. The more exalted the Founding Father, the greater the temptation for comeuppance. At Mount Rushmore in South Dakota, the faces of four American presidents are chiseled into granite and soar 18 meters high. Although the stone-faced presidents can probably withstand a nuclear detonation, the legacy of each is vulnerable to googling [fill in the name] and "war crime." Inasmuch as we should judge our leaders by the values of our times, recent occupants of the White House will fare much worse than Washington, Jefferson, Roosevelt and Lincoln. When queried whether every US president since 1945 could be tried for war crimes, Chomsky responded that such accusations "would be a fair statement by the principles of Nuremberg." With ever-faster search engines, modern presidents ignore their critics at great peril.

After leaving office in disgrace, Richard M. Nixon composed a 1,000 page memoir in an heroic attempt at self-rehabilitation (1978). Other less talented presidents have outsourced the task. Curiously, some have tried not 
only to re-write history but to re-do it. Jimmy Carter and William Clinton joined former Brazilian president José Enrique Cardoso to denounce the international "drug war." The medium was a slick documentary entitled "Quebrando o Tabu" [Breaking the Taboo] (Grostein, 2012). Pity none of them broke the taboo while in office. Retrieval of archival news clips may produce embarrassing clips for uploading on YouTube.

What will be Obama's legacy? Stakes are high on a number of fronts. According to the executive director of the nationwide Sierra Club, "Whatever damage approving the [Keystone] pipeline would do to the environmental movement pales in comparison to the damage it could do to his own legacy" (Broder, et al., 2012). The carrot should accompany the stick. By spearheading delegated delegation, Obama can create a legacy that is truly sustainable. How do the climatologists view Keystone?

An executive agenda pro delegating delegation would rebound over natural history. Rephrasing Wilson, it would be the decision our descendants are most likely to celebrate. Nevertheless, the principal-agent problem looms large, especially in the US where the Supreme Court removed limits on campaign contributions in the 2010 decision Citizens United v. Federal Election Commission (2010). Any whiff of fickleness on the part of a political candidate will be picked up by donors and purses will snap shut. The work of the evolutionary psychologists Leda Cosmides and John Tooby shows just how fine-tuned are humans in detecting deception (1992). For a US President to be celebrated by future generations, he or she will have to become an unexpected entrepreneur of enlightenment. To mix metaphors, an epiphany is the deux ex machina to prevent the tragedy of unpersuasive power. From the viewpoint of the donor, the more apt metaphor is Frankenstein.

The emphasis on the US is not just illustrative. The Economist is correct. The US is an "indispensable nation" in the solution to grave threats of global dimensions. The Nagoya Protocol explicitly recognizes such stature through Article 24 "Non-Parties" which applies to just four countries. The other three are Andorra, The Holy See and South Sudan.

\section{6. iBOL as an enabler of $A B S$ and $A B S$ as an enabler of $\mathrm{BBOL}$}

Technical solutions may require technology not yet extant. Occasionally acceptance of the solution will justify government financing and one thinks of the Manhattan Project, albeit an unfortunate example. Such mobilization of resources was not the case for "The Rationale, Design, and Implementation of the Gargantuan Database" elaborated in chapter 7 of the 1994 book Genes for Sale (Vogel). The reaction to the technology envisioned was ridicule. One of the few reviews was entitled "Genes for Sale; Gargantuan Computer System Wanted" (Rolston, 1995).

At around the same time that Genes for Sale was being ignored, the cost of gene sequencing was undergoing exponential decay, thereby enabling DNA Barcoding, the brainchild of Paul Hebert of the University of Guelph. According to Greg Singer, the first project manager of the International Barcode of Life (iBOL): "The concept is simple but powerful: to build a library of short, standardized pieces of DNA from all of Earth's species that would enable the scientific community to quickly and accurately assess the Earth's biodiversity and monitor it over time" (2009).

In October 2010, iBOL was launched and the subsequent success has been nothing less than meteoric. As of 29 August 2013, the website reports 2,012,391 specimens deposited and 172,280 species named with targets set of 5 million specimens and a half million named species by 2015 . A promotional poster succinctly lays out the vision: "iBOL is building the world in which one can know the name of any animal, any plant, any fungus, any organism, on the spot, in an instant, and anywhere on the planet" (International Barcode of Life, 2009).

iBOL can enable an International Regime on ABS to distribute the proceeds of a fixed royalty, with the shares proportional to the habitat of the countries of origin. But how can ABS enable iBOL? The answer is money. Chapter 9 of Genes for Sale was entitled "Finance" and posed the question "Who Will Finance the Gargantuan Database?" For natural information geographically dispersed, the transactions costs of distributing the royalties will often be greater than the proceeds collected. In such scenarios, the money "should be used to diminish the fixed costs of the gargantuan database" (Vogel, 1994). In other words, ABS enables iBOL through the royalties collected on biotechnologies that derive from ubiquitous natural information. Optimists about the Nagoya Protocol should note well: the proportionality inherent in calculating a country's share of collected royalties achieves the objective of Article 1 that links ABS to conservation and sustainable use.

\section{A Natural Experiment Most Apropos}

A side event at COP10 was entitled "Nothing in the International Regime Makes Sense Except in the Light of The Economics of Information," evoking Theodosius Dobzhansky's "Nothing in Biology Makes Sense Except in the Light of Evolution" (1973). "Seen in the light of [the economics of information], [ABS] is, perhaps, 
intellectually the most satisfying and inspiring [policy of sustainable development]. Without that light it becomes a pile of [stakeholder conflicts] some of them [reconcilable] or [tractable] but [offering] no [significant benefits] as a whole."

Do the experts on ABS so see it? An answer can be gleaned from the Online Discussion Groups on the Need for and Modalities of a Global Multilateral Mechanism held from 8 April to 24 May 2013. One hundred and forty-two experts participated. The sole economist tried "to make sense of [ABS] in the light of [the economics of information]" and explore "the strength and acceptance of the theory" (Dobzhansky, 1973). If "the deciders" within the Secretariat were to allow logic and evidence to prevail, then the tragedy of unpersuasive power would be refuted. If they did not, then it would remain a working hypothesis.

Twelve weeks after the Forum closed, the Secretariat published a 17,500-word "Synthesis of the Online Discussions on Article 10 of The Nagoya Protocol on Access and Benefit-sharing" (CBD Secretariat, 2013a). Although 47 of the 350 interventions referred to "economics" and 22, to "the economics of information," neither the discipline nor the field was cited once. Simlarly expunged was any mention of "genetic material" as a category mistake in the CBD, despite multiple interventions which stressed the "foundational flaw" (ABS Clearing House, 2013, \#4871, \#4891, \#4912, \#5028, \#5284).

"Natural information"entered the Synthesis but only sideways: "A representative of an NGO expressed the view that transboundary resources are the norm if genetic resources are understood as natural information". "Understood" implies an option whereas the correct past participle is "recognized." The casual reader of the Synthesis would not suspect that "natural information" had been assimilated by the second of the four rounds in the Forum. One expert deployed the term ten times in a single intervention (ABS Clearing House, 2013, \#5000). Another found "the logic of bounded openness over natural information ... fairly unassailable" (ABS Clearing House, 2013, \#5191). The strength and acceptance of the theory became evident in "the summary conclusion for the African Group" (ABS Clearing House, 2013, \#5298), which could not be safely ignored. Thus the page-long passage "Bounded Openness" in the Synthesis is followed by an equally long list of "challenges" even though most of the issues were addressed in the discussions. Ironically, the only true challenge to "bounded openness" is its presentation in the Synthesis without the light of economics.

Items 3 to 5 of the Provisional Agenda for the Expert Meeting call for the twenty-five participants invited to Montreal on 17 September 2013 "to review the [S]ynthesis," identify "potential areas of common understanding" and consider "areas for further examination" (CBD Secretariat, 2013b). Given the carefully crafted biases, the only hope lay in the last phrase of Item 3, which allows rejection of the Synthesis for not "captur[ing] the different perspectives raised during the online discussions." However, the raison d'être of the Expert Meeting is "to take up the synthesis document." Should invitees instinctually identify with the ephemeral group, the tragedy will unfold.

\section{Contextualizing Delegated Delegation in the History of Thought}

In a graduate seminar on non-neoclassical economics, Harvey Leibenstein would poke fun at the pendular nature of his own profession. Unlike the natural sciences where a frontier was clearly identifiable, economics was amorphous. Moreover, discarded theories could be rehabilitated. One thinks of Keynes and Malthus or more recently, Paul Krugman and John Kenneth Galbraith (Salerno, 2012). Wilson's rehabilitation of group selection and human instinct shows how wrong Leibenstein was. Science too can swing. What is now ripe for rehabilitation is Thorstein Veblen, one of America's most original thinkers and savage critics (Saad, 2007). A favorite Veblenism from early twentieth century America was "the triumph of imbecile institutions" (Veblen, 1914). Progress was largely a technical problem thwarted by the "captains of industry" and the public who adulated them. For the grave threats of today, governments would do well to dust off Veblen and institutionalize his implicit advice, viz., delegated delegation.

The tragedy of unpersuasive power is the complement to the tragedy of the commons. For problems with no technical solution, the recommendation from Hardin is "mutual coercion, mutually agreed upon" (Hardin, 1968); for problems with known technical solutions, the complementary recommendation is delegated delegation. As the quote from Krauss that opens this essay makes clear, delegated delegation is not underway. Scientific bodies in the most indispensable country in the world, namely, the US, wield insufficient power. To make matters worse, the few scientists inside the policy loop are often chosen for their willingness to "team play" with the non-scientists, who both outnumber and outmaneuver them. Gamesmanship rules.

Despite the dismal scenario, there is reason for hope. A US president who makes a concerted effort toward delegated delegation will be richly rewarded, incommensurably so. Legacies are in the balance and easy pickings 
await in known technical solutions. ABS is just one salient example. Climate transformation and nuclear non-proliferation may serve equally well.

Seen from the larger sweep of natural history, Homo sapiens are now sailing between the Scylla and Charybdis of groupthink and studied ignorance. Wreckage would be an anthropogenic holocaust. The compass for safe passage is awareness of both the Enlightenment Fallacy and the Post-Modern Fallacy. Open waters lay ahead.

\section{Acknowledgemetns}

Comments to early drafts by Klaus Angerer, Paul Bayman, Newton Fawcett, Camilo Gomides, Steven E. Massey, Omar Oduardo-Sierra and Manuel Ruiz were especially appreciated. Support has been provided by the Peruvian Society for Environmental Law. The usual disclaimer applies.

\section{References}

ABS-Clearing House. (2013). Search the Discussion Groups. Retrieved from http://absch.cbd.int/searchforum.shtml

Adrey, R. (1966). The territorial imperative. New York: Dell Publishing.

Barash, D. P., \& Lipton, J. E. (2010). How the scientist got his ideas. The Chronicle Review. Retrieved from http://chronicle.com/article/How-the-Scientist-Got-His/63287/

Blinder, A. S. (1997). Is Government Too Political? Foreign Affairs, 76(6), 115-126. http://dx.doi.org/10.2307/20048280

Broder J. M., Krauss, C., \& Austen, I. (2012). Obama faces risks in pipeline decision. The New York Times (p.2).

Buck M. B., \& Hamilton, C. (2011). The Nagoya Protocol on Access to Genetic Resources and the Fair and Equitable Sharing of Benefits Arising from their Utilization to the Convention on Biological Diversity. RECIEL, 20(1), 47-61.

CBCNEWS. (2009). Obama's G-20 Press Conference. Retrieved from http://www.cbsnews.com/stories/2009/04/02/politics/100days/worldaffairs/main4914735.shtml

CBD Secretariat. (2013a). Synthesis of the online discussions on Article 10 of the Nagoya Protocol on Access and Benefit-sharing. UNEP/CBD/ABSEM-A10/1/2. Retrieved from http://www.cbd.int/doc/?meeting=ABSEM-A10-01

CBD Secretariat. (2013b). Annotated Provisional Agenda. UNEP/CBD/ABSEM-A10/1/1/Add.1. Retrieved from http://www.cbd.int/doc/?meeting=ABSEM-A10-01

Chomsky, N. (2013). Power systems. New York: Henry Holt and Company.

Citizens United. (2010). Federal Election Commission, 558, U.S. 310.

Cosmides, L., \& Tooby, J. (1992). Cognitive adaptations for social exchange. The Adapted Mind (pp.163-228). New York: Oxford University Press. Retrieved from http://www.cep.ucsb.edu/papers/Cogadapt.pdf

Daly, H. (1991). Steady-state economics (2nd Ed.). Washington, D.C.: Island Press.

Dawkins, R. (1976). The selfish gene. New York: Oxford University Press.

Dobzhansky, T. (1973). Nothing in biology makes sense except in the light of evolution. The American Biology Teacher, 35, 125-129. http://dx.doi.org/10.2307/4444260

Ehrlich, P. R., \& Ehrlich, A. H. (2004). One with Nineveh. Washington, D.C.: Island Press.

Eisenberg, L. (1972). The human nature of human nature. Science, 176(4031), 123-128. http://dx.doi.org/10.1126/science.176.4031.123

Gore, A. (2006). An inconvenient truth. New York: Rodale.

Gould, S. J. (1978). Sociobiology: the art of storytelling. New Scientist, 16, 530-533.

Greiber T, Peña Moreno, S., Åhrén, M., Nieto Carrasco, J., \& Kamau, E. C. (2012). An Explanatory Guide to the Nagoya Protocol on Access and Benefit-Sharing. IUCN. Retrieved from https://cmsdata.iucn.org/downloads/an_explanatory_guide_to_the_nagoya_protocol.pdf

Grostein Andrade, F. (2012). Quebrando o tabu. Sundog Pictures.

Hardin, G. (1968). The tragedy of the commons. Science, 162, 1243-1248. http://dx.doi.org/10.1126/science.162.3859.1243 
Hrdy, S. (1981). The women that never evolved. Cambridge: Harvard University Press.

ICTSD. (2010). CBD reaches agreement on access and benefit sharing, but some question its effectiveness. Bridges Weekly Trade News Digest, 14, 38. http://ictsd.org/i/news/bridgesweekly/92903/

International Barcode of Life. (2009). International Barcode of Life Project. Retrieved from http://absbonn.pbworks.com/f/iBOL-FactSheet_English.pdf

Kamau, E. C., Fedder, B., \& Winter, G. (2010). The Nagoya Protocol on Access to Genetic Resources and Benefit Sharing: What is new and what are the implications for provider and user countries and the scientific community? Law, Environment and Development Journal, 6(3), 246-262. http://www.lead-journal.org/content/10246.pdf

Keynes, J. M. (1923). A tract on monetary reform. London: Macmillan.

Keynes, J. M. (1936). The general theory of employment, interest and money. London: Macmillian.

Kitcher, P. (1985). Vaulting ambition: sociobiology and the quest for human nature. Cambridge: The MIT Press.

Knight, R. L. (2013). Australian dictionary of biography (pp.1811-1892). In Lowe \& Robert (Eds.). Retrieved from http://adb.anu.edu.au/biography/lowe-robert-2376

Krauss, L. (2013). Deafness at doomsday. New York Times (p.A23).

Krugman, P. (2013). Sequester of fools. New York Times (p.A23).

Krugman, P. (2013). Austerity, Italian style. New York Times (p.A17).

Leijonhufvud, A. (1968). On Keynesian economics and the economics of Keynes. New York: Oxford University Press.

Lumsden C. J., \& Wilson, E. O. (1981a). Genes, mind, culture. Cambridge: Harvard University Press.

Lumsden C. J., \& Wilson, E. O. (1981b). Promethean fire. Cambridge: Harvard University Press.

Mancur, O. (1965). The logic of collective action. Cambridge: Harvard University Press.

Marrero-Girona, G., \& Vogel, J. H. (2012). Can 'monkey business' resolve the most contentious issue in the Convention on Biological Diversity? International Journal of Psychological Studies, 4(1), 55-65. http://dx.doi.org/10.539/ijps.v4n1p55

Nixon, R. (1978). The memoirs of Richard Nixon. New York: Touchstone.

Nobelprize.org. (2013). All prizes in economic sciences. Retrieved from http://www.nobelprize.org/nobel_prizes/economics/laureates/

Obama, B. (2013). The 2013 State of the Union. Retrieved from http://www.whitehouse.gov/state-of-the-union-2013

Oduardo-Sierra O., Vogel, J. H., \& Hocking, B. A. (2012). Monitoring and tracking the economics of information in the Convention on Biological Diversity: studied ignorance (2002-2011). Journal of Politics and Law, 5(2), 29-39. http://dx.doi.org/10.5539/jpl.v5n2p29

Renner S. C., Neumann, D., Burkart, M., Feit, U., \& Giere, P. (2012). Import and export of biological samples from tropical countries-considerations and guidelines for research teams. Org Divers Evol, 12, 81-98. http://dx.doi.org/10.1007/s13127-012-0076-4

Robbins, L. (1932). An essay on the nature and significance of economic science. London: Macmillan.

Rolston III, H. (1995). Genes for sale; gargantuan computer system wanted. Conservation Biology, 9, 1657-1658. http://dx.doi.org/10.1046/j.1523-1739.1995.09061657-3.x

Ruiz, M., Vogel J. H., \& Zamudio, T. (2010). Logic should prevail: a new theoretical and operational framework for the International Regime on Access to Genetic Resources, and the Fair and Equitable Sharing of Benefits. Initiative for the Prevention of Biopiracy Research Documents, 13(6), 1-12. http://www.spda.org.pe/portal/_data/spda/documentos/20100316110250_Serie\%2013\%20Ingles.pdf

Saad, G. (2007). The evolutionary bases of consumption. Mahwah, NJ: LEA/Psychology Press.

Salerno, J. T. (2012). Gaga over Galbraith. Ludwig von Mises Institute. Retrieved from http://mises.org/daily/6231/Gaga-Over-Galbraith)

Samuelson, P., \& Nordhaus, W. (2005). ECONOMICS (18th Ed.). New York: McGraw-Hill. 
Singer, G. (2009). Report on the session "Barcoding of life: society and technology dynamics - global and national perspectives," held at the Third International Barcode of Life Conference in Mexico City, MX, November 9th, 2009. Retrieved from https://www.cbd.int/doc/meetings/abs/abswg-09-3rd/information/abswg-09-3rd-inf-15-en.pdf

Soros, G. (2010). The Soros lectures. New York: PUBLICAFFAIRS.

Stiglitz, J. (1987). Principal and agent. The new Palgrave: a dictionary of economics v. 3.

Stiglitz, J. (2008). Economic foundations of intellectual property rights. Duke Law Journal, 57, 1693-1724.

The Economist. (2013). How will history see me? (pp.26-28).

The Nizkor Project. (2013). Fallacies. Retrieved from http://www.nizkor.org/features/fallacies/

United Nations Convention on Biological Diversity. (1992). Article 1. Retrieved from http://www.cbd.int/doc/legal/cbd-en.pdf

United Nations Convention on Biological Diversity. (2012). Report of the Eleventh Meeting of the Conference of the Parties. Retrieved from http://www.cbd.int/doc/meetings/cop/cop-11/official/cop-11-35-en.pdf

Veblen, T. (1914). The instinct of workmanship. New York: The Macmillan Company.

Vernooy, R., \& Ruiz, M. (2012). Introduction: widening the horizon. In M. Ruiz \& R. Vernooy (Eds.), The custodians of biodiversity (pp.3-9). New York: Earthscan.

Vogel, J. H., Álvarez-Berríos, N., Quiñones-Vilche, N., Medina-Muñiz, J. L., \& Pérez-Montes, D. (2011). The economics of information, studiously ignored in the Nagoya Protocol on Access and Benefit Sharing. Law, Environment and Development Journal, 7(1): 51-65. http://www.lead-journal.org/content/11052.pdf

Vogel, J. H., Fuentes, C. R., Hocking, B. A., Oduardo-Sierra, O., \& Zubiaurre, A. (2013). Human pathogens as capstone application of the economics of information to Convention on Biological Diversity. International Journal of Biology, 5(2), 121-134. http://dx.doi.org/10.5539/ijb.v5n2p121

Vogel, J. H. (1994). Genes for sale. New York: Oxford University Press.

Vogel, J. H. (2007). Reflecting financial and other incentives of the TMOIFGR: the biodiversity cartel. In M. Ruiz \& I. Lapeña (Eds.), A moving target: genetic resources and options for tracking and monitoring their international flows (pp.47-74). Gland, Switzerland: IUCN. Retrieved from http://data.iucn.org/dbtw-wpd/edocs/EPLP-067-3.pdf

Vogel, J. H. (2012). Epilogue: architecture by committee and the conceptual integrity of the Nagoya Protocol. In M. Ruiz \& R. Vernooy (Eds.) The custodians of biodiversity: sharing access to and benefits of genetic resources (pp.181-188). New York: Earthscan. Retrieved from http://idl-bnc.idrc.ca/dspace/bitstream/10625/47481/1/IDL-47481.pdf

Watanabe, K., \& Teh, G. H. (2011). Wanted: bioprospecting consultants. Nature Biotechnology, 10, 873-875. http://dx.doi.org/10.1038/nbt.2001

West, S. (2012). Institutionalized exclusion: the political economy of benefit sharing and intellectual property. Law, Environment and Development Journal, 8(1), 19-41. http://www.lead-journal.org/content/12019.pdf

Wilson, E. O. (1975). Sociobiology (p.547). Cambridge, Mass: Harvard University Press.

Wilson, E. O. (1976). Academic vigilantism and the political significance of Sociobiology. BioScience, 26(3), 187-190. http://dx.doi.org/10.2307/1297247

Wilson, E. O. (1994). The naturalist (p.345). Washington, DC: Island Press. http://dx.doi.org/10.1086/285604

Wilson, E. O. (1998). Consilience (p.4). New York: Alfred A. Knopf.

Wilson, E. O. (2002). The future of life. New York: Random House.

Wilson, E. O. (2012). The social conquest of Earth. New York: W.W. Norton.

\section{Copyrights}

Copyright for this article is retained by the author(s), with first publication rights granted to the journal.

This is an open-access article distributed under the terms and conditions of the Creative Commons Attribution license (http://creativecommons.org/licenses/by/3.0/). 